\title{
Carlos Manuel Reglero de la Fuente, MONASTERIOS Y MONACATO EN LA ESPAÑA MEDIEVAL, Madrid, Marcial Pons Historia, 2021, 445 págs. ISBN: 978-84-17945-25-1.
}

\author{
Francisco JaVier Pérez Rodríguez \\ Universidad de Vigo
}

En estos últimos años Marcial Pons, Ediciones de Historia, en su sección de Estudios de Historia Medieval ha publicado una serie de monografías de gran calidad dedicada al conjunto de la Península Ibérica, o de España, sobre un período determinado, como la época visigoda, de Javier Arce (2017), o sobre un tema concreto, como La construcción del poder real en la Monarquía castellana (siglos XI-XV), de José María Monsalvo (2019). En una época en que la historiografía se ha multiplicado es de agradecer que se ofrezcan visiones de conjunto que recojan las aportaciones hechas en las últimas décadas y que se haga, además, de una forma que, sin olvidar el rigor científico, la obra pueda llegar al gran público. En esta línea se inscribe este Monasterios y monacato en la España medieval de Carlos M. Reglero, autor que, con un demostrado conocimiento del tema gracias a sus numerosos estudios previos, lo trata con maestría, ofreciendo una obra a todas luces exitosa.

El trabajo se organiza de forma clásica, cronológicamente, en tres grandes partes que coinciden con los períodos en que suele dividirse la Historia medieval europea: «El monacato en la Alta Edad Media (siglos IX-XI)», «La introducción del monacato hispano en el mundo de las órdenes religiosas (fines siglos XI-fines siglo XIII)» y «Crisis y reformas en la Baja Edad Media (siglos XIV-XV)», precedidas por una introducción y seguidas por unas breves conclusiones, la pertinente lista bibliográfica y, por último, un índice onomástico y otro toponímico. La inclusión de estos índices, que no suelen ser corrientes en las ediciones de los últimos años, es otra de las razones que abundan en la calidad de la obra, facilitando su consulta, y que hemos de agradecer a la editorial Marcial Pons, que los incluye en sus monografías dedicadas a la Historia.

En la breve introducción Reglero expone claramente los objetivos de la obra: el monacato hispano medieval en su conjunto, los monasterios entendidos no como edificios u objetos de la Historia del Arte, sino como las comunidades que los levantaron y habitaron. En este sentido, el trabajo «se aborda desde el anacoretismo al cenobitismo, desde la clausura estricta hasta el afán predicador de los mendicantes» (p. 15) en el 
conjunto de los reinos medievales que conforman la España actual, esto es, dejando fuera al reino ibérico de Portugal.

De las tres grandes partes en que se estructura el trabajo, la primera se dedica al largo período que media entre los siglos IV y XI, dividiéndose en tres capítulos de los cuales, el primero, tras un breve repaso de los orígenes del monacato cristiano, analiza las características que adoptó en la Hispania visigoda, base sobre la cual se desarrolla el monacato que lo sucedió tras la invasión musulmana, tanto en al-Ándalus como en los territorios que pronto dejaron de estar bajo dominio islámico, al que se dedica el segundo capítulo. El tercero se centra en «las comunidades y su forma de vida», dentro del cual creo que merece la pena destacar las páginas destinadas a «Entre la tradición visigoda y la Regla de San Benito», donde el autor analiza el conocimiento de esta y su influencia en el monacato hispano de los siglos IX y X para terminar con la proyección que tuvo la gran casa borgoñona de San Pedro de Cluny en esta última centuria y en la siguiente, aumentando el prestigio de la regla benedictina en los reinos peninsulares.

La segunda parte, dedicada al período plenomedieval, es la más extensa de las tres, la única que contiene cuatro capítulos y se inicia, significativamente, con el titulado «El triunfo de la Regla de San Benito». Reglero muestra la difusión de la costumbre benedictina de Cluny, más exitosa que la de la propia congregación, el éxito posterior de Císter más toda la serie de problemas con el episcopado, la organización de cada orden, el nacimiento de las militares y la especificidad del monacato femenino, que tuvo que adaptarse a las nuevas circunstancias, con la escasa presencia de Fontevrault y la singular fundación de las Huelgas de Burgos, excepcional a varios niveles. En el capítulo siguiente, «Canónigos, cartujos y mendicantes», creo que deben destacarse las páginas que el autor dedica a los primeros, pues los cenobios agustinos a menudo han pasado desapercibidos, sin alcanzar el reconocimiento de benedictinos y cistercienses, a pesar incluso de la importancia que tuvieron, por ejemplo, los premonstratenses en el reino de Castilla. Por su parte, los siempre minoritarios cartujos apenas llegaron a tener tres casas, todas en la Corona de Aragón, dos de ellas en Cataluña y una en el reino de Valencia. A continuación se analiza el nacimiento de las órdenes mendicantes y su rápida difusión por la Península, distinguiendo de nuevo las ramas masculinas de las femeninas. Tras mostrar la creación, difusión y expansión de las distintas ramas del monacato, el siguiente capítulo, «Monasterios y sociedad», se dedica, especialmente, a los cambios sufridos por los cenobios respecto a la etapa anterior y a la relación que se mantiene, sobre todo, con monarquía y aristocracia, dedicándose un subapartado a mostrar cómo se organizan los dominios y se lleva a cabo su gestión. Por último, y de la misma forma que en la primera parte, el último capítulo versa sobre «las comunidades monásticas y su forma de vida», analizándose las comunidades por dentro, mostrando su organización interna en este su período de plenitud plenomedieval, para acabar con la actividad cultural desarrollada en monasterios y conventos.

La tercera sección, dedicada al monacato bajomedieval, es la menos extensa de las tres, sin llegar al centenar de páginas que ampliamente rebasan las dos anteriores, mostrando la menor atención que, en general y salvo excepciones, ha mostrado la historiografía a 
una etapa que solo aparentemente es menos brillante que la anterior. Dividida en tres capítulos, el primero se dedica a los cambios de actitud de monarquía y aristocracia respecto a los monasterios así como a la actividad cultural de estos para, a continuación, en el segundo, centrarse en «Los problemas temporales y espirituales» de los cenobios, sumidos en una crisis tanto económica como disciplinaria que dará lugar en buena medida a «Las reformas monásticas» que se analizan en el décimo y último capítulo de la obra. En función de la bibliografía existente, el desarrollo de cada una de estas reformas se observa de manera desigual, pues es mejor conocida, por ejemplo, la difusión de la Cartuja y su conexión con la monarquía que el desarrollo, largo y complicado, de la reforma observante franciscana o cisterciense, que se prolonga más allá de los límites temporales del Medievo.

Monasterios y monacato en la España medieval es, indudablemente, una monografía que viene a llenar un hueco en la historiografía medieval hispana al dar una visión de conjunto sobre el tema en una amplia cronología. El autor ofrece la enorme variedad que se oculta tras una realidad que puede suponerse relativamente estática, mostrando la evolución de la vida comunitaria dedicada a Dios a lo largo de más de mil años que ocupa la Edad Media. De forma rápida y concisa discurren las sucesivas reglas monásticas y las interpretaciones que de ellas se hicieron, poniendo de relieve las etapas en las que fueron más destacadas las tendencias anacoréticas, cómo se fueron conformando las redes monásticas, sus transformaciones y las cambiantes relaciones con otras instituciones y con la sociedad contemporánea, en especial con sus capas altas -monarquía y aristocracia-. La importancia que, en especial a partir de finales del siglo XI, adquiere la regla benedictina, adoptada por cluniacenses y cistercienses, no hace olvidar la presencia de otras de menor relieve, como agustinos, premonstratenses o cartujos, ni tampoco las ramas femeninas de las distintas órdenes. Hay, además, que resaltar cómo el autor ha evitado el tópico que suele acompañar a las monografías dedicadas al monacato. Aunque sin, por supuesto, olvidarlo, Reglero pasa rápidamente por encima del ora et labora típicamente benedictino para centrarse en muchas otras cuestiones y mostrando cómo una misma regla fue leída, interpretada y reinterpretada de muchas maneras a lo largo del tiempo. La huida del tópico es plenamente consciente, como lo pone de relieve el propio autor en sus conclusiones al referirse al papel cultural de los monasterios medievales y que creo merece la pena citar: «Sin duda los scriptoria monásticos desempeñaron un papel destacado en la copia y transmisión de libros, pero con frecuencia menor que el de las catedrales, a menudo olvidadas, cuyas bibliotecas estuvieron mejor provistas» (p. 385). Tal afirmación, que el autor matiza, muestra a las claras que estamos ante la obra de un especialista que expone los resultados de varias décadas de investigaciones previas, incluidas las suyas propias, sobre el tema, ilustrando la variedad de un monacato que, necesariamente, tiene que haber sido diverso al tratarse su evolución durante más de un milenio. 